\title{
Full Length Bid is sufficient to induce apoptosis of cultured rat
} hippocampal neurons

\author{
Hans-Georg König1, Markus Rehm¹, Daniel Gudorf², Stan Krajewski³, \\ Atan Gross ${ }^{4}$, Manus W Ward ${ }^{1}$ and Jochen HM Prehn*1
}

Address: ${ }^{1}$ Department of Physiology and RCSI Neuroscience Research Centre, Royal College of Surgeons in Ireland, 123 St Stephen's Green, Dublin 2, Ireland, 2 Interdisciplinary Center for Clinical Research, University Münster Clinics, D-48149 Münster, Germany, ${ }^{3}$ The Burnham Institute, Program on Apoptosis and Cell Death, La Jolla, CA 92037, USA and ${ }^{4}$ Department of Biological Regulation, Weizmann Institute of Science, Rehovot 76100, Israel

Email: Hans-Georg König - hgkoenig@rcsi.ie; Markus Rehm - mrehm@rcsi.ie; Daniel Gudorf - danielgudorf@onlinehome.de; Stan Krajewski - stan@burnham.org; Atan Gross - atan.gross@weizmann.ac.il; Manus W Ward - mward2@rcsi.ie;

Jochen HM Prehn* - prehn@rcsi.ie

* Corresponding author

Published: 27 February 2007

BMC Cell Biology 2007, 8:7 doi:10.1186/147I-2121-8-7

This article is available from: http://www.biomedcentral.com/I47I-2/2I/8/7

(c) 2007 König et al; licensee BioMed Central Ltd.

This is an Open Access article distributed under the terms of the Creative Commons Attribution License (http://creativecommons.org/licenses/by/2.0), which permits unrestricted use, distribution, and reproduction in any medium, provided the original work is properly cited.

\begin{abstract}
Background: $\mathrm{Bcl}-2$ homology domain $(\mathrm{BH}) 3$-only proteins are pro-apoptotic proteins of the $\mathrm{Bcl}-$ 2 family that couple stress signals to the mitochondrial cell death pathways. The $\mathrm{BH} 3$-only protein Bid can be activated in response to death receptor activation via caspase 8-mediated cleavage into a truncated protein (tBid), which subsequently translocates to mitochondria and induces the release of cytochrome-C. Using a single-cell imaging approach of Bid cleavage and translocation during apoptosis, we have recently demonstrated that, in contrast to death receptor-induced apoptosis, caspase-independent excitotoxic apoptosis involves a translocation of full length Bid (FL$\mathrm{Bid}$ ) from the cytosol to mitochondria. We induced a delayed excitotoxic cell death in cultured rat hippocampal neurons by a 5 -min exposure to the glutamate receptor agonist $\mathrm{N}$-methyl-Daspartate (NMDA; $300 \mu \mathrm{M})$.
\end{abstract}

Results: Western blot experiments confirmed a translocation of FL-Bid to the mitochondria during excitotoxic apoptosis that was associated with the release of cytochrome-C from mitochondria. These results were confirmed by immunofluorescence analysis of Bid translocation during excitotoxic cell death using an antibody raised against the amino acids $\mathrm{I}-58$ of mouse Bid that is not able to detect tBid. Finally, inducible overexpression of FL-Bid or a Bid mutant that can not be cleaved by caspase- 8 was sufficient to induce apoptosis in the hippocampal neuron cultures.

Conclusion: Our data suggest that translocation of FL-Bid is sufficient for the activation of mitochondrial cell death pathways in response to glutamate receptor overactivation.

\section{Background}

Excitotoxic neuron death has been implicated in the pathogenesis of ischemic, traumatic, and seizure-induced brain injury [1]. When glutamate receptor overactivation is intense, cell death is necrotic and characterized by a disturbance of cellular ion and volume homeostasis, leading to mitochondrial membrane potential $(\Delta \Psi \mathrm{m})$ depolarization, free radical production, ATP depletion and early 
plasma membrane leakage [2-5]. However, when glutamate receptor overactivation is subtle, mitochondria transiently recover their energetics, and a delayed cell death may result $[3,6,7]$. Under these conditions, excitotoxic neuron death is associated with the release of the proapoptotic factors cytochrome-C (cyt-C) and ApoptosisInducing Factor (AIF) from mitochondria [6-10].

The mechanisms of cyt-C and AIF release during excitotoxic neuron death remain unresolved. In the evolutionary conserved apoptosis pathway, the release of cyt-C requires the pro-apoptotic Bcl-2 family members Bax or Bak [11]. Both proteins are believed to form megachannels in the outer mitochondrial membrane large enough to release intermembrane space proteins [12]. In order to cause this increased permeability, Bax and Bak undergo a conformational change and insert into the outer mitochondrial membrane $[13,14]$. In non-apoptotic cells, activation of Bax or Bak is inhibited by anti-apoptotic Bcl-2 family members such as Bcl-2 and Bcl-xL. In apoptotic cells, the transcriptional induction or post-translational activation of Bcl-2-homolgy domain-3 (BH3)-only proteins overcomes this inhibition and triggers the activation of Bax and Bak and the release of cyt-C $[15,16]$. The release of AIF in excitotoxicity and apoptosis is likewise inhibited by Bcl-2 [10,17], suggesting that the activation of $\mathrm{BH} 3$-only proteins may also be required to relieve a Bcl2 inhibition of AIF release.

Previous studies have indicated an involvement of the BH3-only protein Bad in glutamate- and $\mathrm{Ca}^{2+}$-induced neuronal apoptosis [18]. Interestingly, neurons from mice deficient in the BH3-only protein Bid have also been shown to be resistant to ischemic injury in vivo, as well as hypoxic and excitotoxic injury in vitro [19]. Bid is an essential component of most forms of death receptor-mediated apoptosis, and is activated post-translationally via caspase-8-mediated cleavage into a truncated form (tBid) $[20,21]$. tBid is subsequently myristoylated [22], triggers the activation of Bak or Bax $[23,24]$, and induces cyt-C release from mitochondria. However, there is a growing body of evidence suggesting that caspase activation during excitotoxic neuron death may be marginal or even absent [6,8,25-27]. Conversely, this suggests that Bid may trigger excitotoxic cell death through more than one pathway. Using a fluorescence resonance energy transfer single-cell imaging approach of Bid cleavage and translocation during apoptosis, we have recently demonstrated that caspase-independent excitotoxic apoptosis induces a translocation of full length Bid (FL-Bid) from the cytosol to mitochondria [28]. In the present study, we demonstrate FL-Bid is sufficient to induce apoptosis of cultured rat hippocampal neurons.

\section{Results \\ FL-Bid is not a significant protease substrate during excitotoxic neuron death}

To investigate the involvement of apoptotic proteins in excitotoxic neuron death, we recently established a model in which a transient, 5-min exposure to the glutamate receptor agonist NMDA $(300 \mu \mathrm{M})$ induced a delayed cell death in primary cultures of rat hippocampal neurons $[7,8]$. This excitotoxic cell death is characterized by mitochondrial cyt-C release and $\Delta \Psi \mathrm{m}$ depolarization setting in 4 to $8 \mathrm{~h}$ after the NMDA exposure, followed by nuclear condensation and cell shrinkage $[7,8]$. We determined if FL-Bid is able to translocate to mitochondria in this model of excitotoxic apoptosis. To this end, immunoblotting experiments were performed using a rabbit polyclonal antibody (AR-53) that detects p21 FL-Bid, as well as its caspase-8-/caspase-3-generated $\mathrm{NH}_{2}$-terminal cleavage product $[29,30]$. Control experiments demonstrated that the antibody was able to detect FL-Bid and its caspase-generated $\mathrm{NH}_{2}$-terminal p7 fragment in HeLa D98 cells after an activation of death receptors with TNF- $\alpha /$ Cycloheximide(CHX) (Fig. 1A, see also Additional File 1A). The antibody was also able to detect the $\mathrm{p} 7$ fragment in cultured rat hippocampal neurons (Fig. 1B) exposed to the apoptosis-inducing kinase inhibitor staurosporine (STS) or TNF- $\alpha /$ CHX (Fig. 1B see also Additional File 1B). However, neither a decrease in the content of FL-Bid, nor an accumulation of caspase-generated cleavage products could be detected in whole cell lysates of cultured rat hippocampal neurons exposed to NMDA (Fig. 1C, see also Additional File 1C). Activation of proteases after the NMDA exposure was however clearly detectable in the same whole cell lysates. This was evident from the decrease in the calpain I substrate full-length $\alpha$-spectrin and the accumulation of calpain-specific 150 and 145 $\mathrm{kDa} \alpha$-spectrin cleavage products 4 and $8 \mathrm{~h}$ after the NMDA exposure (Fig. 1D).

\section{Translocation of FL-Bid to mitochondria during excitotoxic neuron death}

Next, we performed selective plasma membrane permeabilization and subsequent immunoblotting of the cytosolic fraction and the mitochondria-containing pellet fraction in cultured rat hippocampal neurons exposed to NMDA for $5 \mathrm{~min}$. Immunoblotting with a voltage dependent anion carrier (VDAC) antibody demonstrated that the cytosolic fraction was not contaminated with mitochondria. Immunoblotting with the Bid antibody revealed that p21 FL-Bid translocated from the cytosol to the mitochondria-containing pellet fraction $4 \mathrm{~h}$ and more pronounced $8 \mathrm{~h}$ after termination of the NMDA exposure (Fig. 2A). This process was paralleled by the translocation of cyt-C from the mitochondria-containing pellet fraction to the cytosol (Fig. 2A) $4 \mathrm{~h}$ and $8 \mathrm{~h}$ after the NMDA exposure. Interestingly, despite a significant cyt-C decrease in 
A

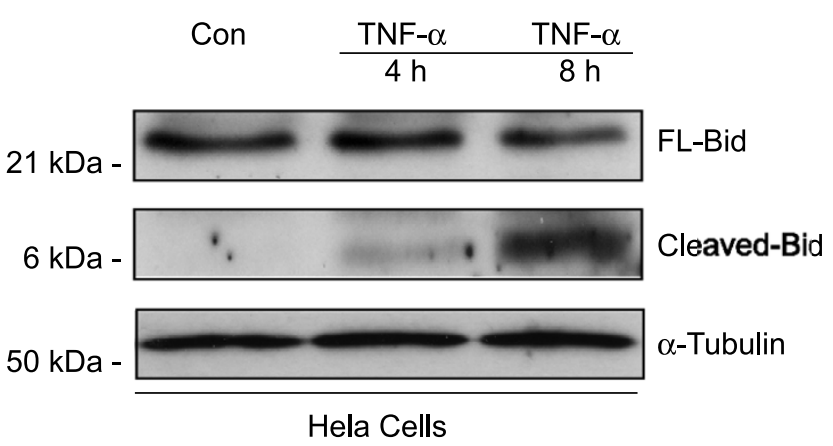

B

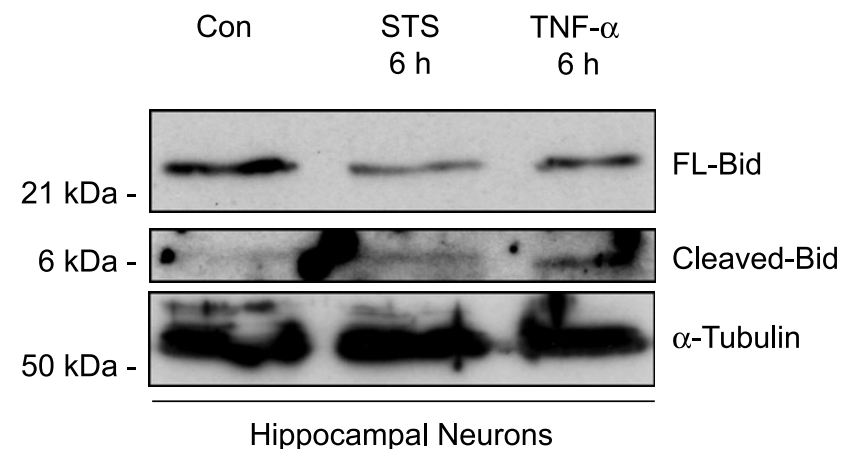

C

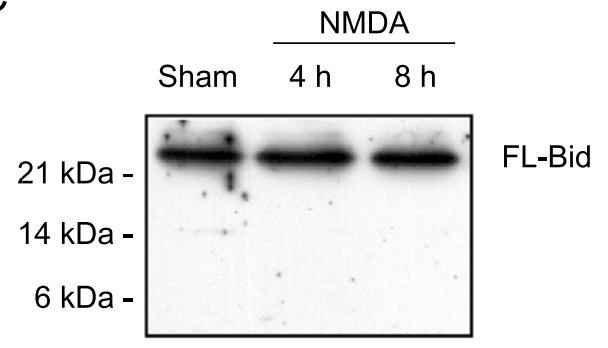

D

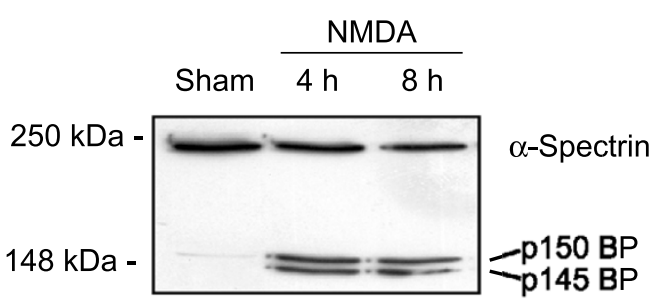

Figure I

Death receptor mediated cleavage of Bid in HeLa cells and cultured rat hippocampal neurons. Cleavage of FL-Bid in HeLa D98 cells (A)and cultured rat hippocampal neurons (B)exposed to TNF- $\alpha$ plus CHX (I00 ng/ml plus I $\mu \mathrm{g} / \mathrm{ml})$ or staurosporine (STS, $3 \mu \mathrm{M}$ and $300 \mathrm{nM}$, respectively) for the indicated time periods. Bid cleavage was detected by Western blot analysis. Duplicate experiments yielded similar results. (C)No detectable cleavage of FL-Bid during NMDA-induced neuronal death. Cultured rat hippocampal neurons were exposed to $300 \mu \mathrm{MNMDA}$ in $\mathrm{Mg}^{2+}$-free HBS for 5 min, washed, returned to the original culture medium, and analyzed by Western blotting after 4 and $8 \mathrm{~h}$. Sham-washed cultures were exposed to $\mathrm{Mg}^{2+}$ free HBS devoid of NMDA. Lack of Bid cleavage during excitotoxic neuron death was observed in four separate experiments. (D)Immunoblot analysis demonstrates significant cleavage of $\alpha$-spectrin into its calpain-generated I50 and I45 kDa breakdown products. Duplicate experiments yielded similar results.

the mitochondrial fraction by $8 \mathrm{~h}$, the cyt-C content in the cytosolic fraction did not increase correspondingly, suggesting that cyt-C may be degraded upon release into the cytosol (see also [31]). Indeed, treatment with the membrane permeable cathepsin inhibitor CA-074 methyl ester recovered the cyt-C content in the cytosolic fraction $8 \mathrm{~h}$ after the NMDA exposure (Fig. 2A).

These results were confirmed by immunofluorescence analysis of Bid redistribution during excitotoxic neuron death using the above described Bid antibody. Neurons of sham-exposed control cultures exhibited a diffuse Bid immunofluorescence signal (Fig. 2B). Cyt-C co-staining revealed a filamentous, punctate staining pattern in shamexposed controls characteristic of mitochondria. In contrast, cells that had released cyt-C in response to NMDA exhibited a clustered Bid immunofluorescence around the nucleus. Cells with released cyt $\mathrm{C}$ and clustered Bid immunofluorescence also exhibited nuclear chromatin condensation as evidenced by staining with the chromatin dye Hoechst 33258 (Fig. 2B).

Mild overexpression of FL-Bid or a Bid mutant that can not be cleaved by caspase- 8 potently induces cell death in cultured rat hippocampal neurons

We subsequently addressed the question, whether FL-Bid was sufficient to induce cell death in the hippocampal neuron cultures, and whether this cell death can occur in the absence of caspase-8-mediated Bid cleavage. Cultured rat hippocampal neurons were infected with adenoviral vectors expressing either FL-Bid or a Bid mutant that can not be cleaved by caspase-8 (D59A) under the control of a tetracycline responsive promoter [32]. Western blot analysis of cultures infected with the adenoviral vectors (50 MOI) and induced for $24 \mathrm{~h}$ with $1 \mu \mathrm{g} / \mathrm{ml}$ doxycycline demonstrated a mild overexpression of FL-Bid in the hippocampal neuron cultures (Fig. 3A). This overexpression was however sufficient to induce a massive cell death in 
A

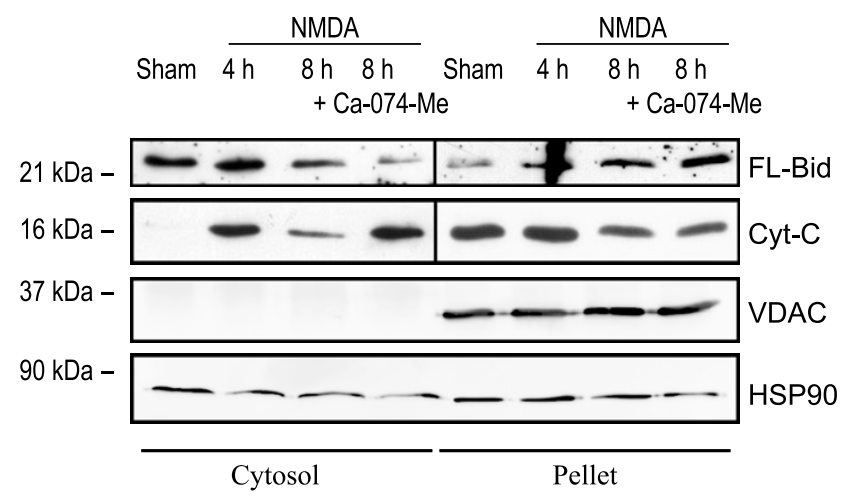

B

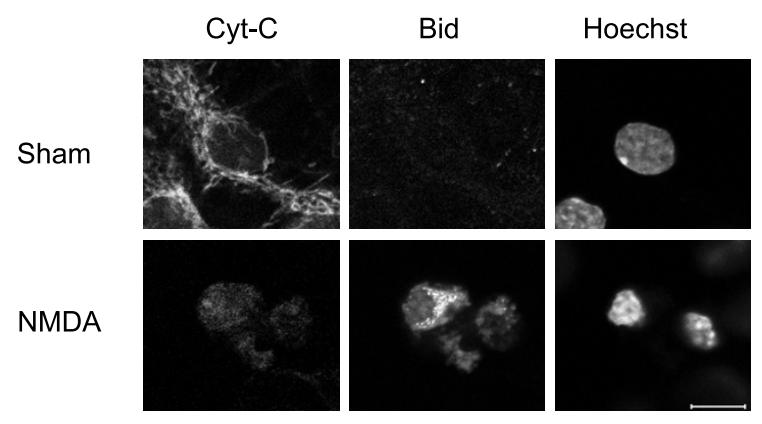

Figure 2

Translocation of FL-Bid to the mitochondria coincides with a loss of cyt-C. (A)Immunoblot analysis of cytosolic and mitochondria-containing pellet fractions after selective plasma membrane permeabilization in cells exposed to $\mathrm{Mg}^{2+}$-free $\mathrm{HBS}$ (controls) or NMDA with or without CA-074-Me. The experiment was performed in duplicate with similar results. (B)Immunofluorescence analysis of cyt-C and Bid distribution in sham- and NMDA-exposed rat hippocampal neurons. Cells were fixed 8 $\mathrm{h}$ after termination of the exposure. Nuclei were counterstained with Hoechst 33258. Scale bar $=5 \mu \mathrm{m}$.

the hippocampal neuron cultures that was characterized by cell shrinkage and nuclear condensation. Hoechst staining of nuclear chromatin revealed significant neuronal damage $24 \mathrm{~h}$ after induction with doxycycline, reaching a level of $80.1 \pm 2.7 \%$ (Fig. 3B). FL-Bid-induced cell death was associated with the mitochondrial release of the pro-apoptotic factors cyt-C and AIF (Fig. 3C and data not shown). In contrast, hippocampal neurons that were infected with the adenoviral vectors but were not induced with doxycycline remained viable for up to $24 \mathrm{~h}$, as were cells that were treated with doxycycline but not infected with the adenoviral vectors (Fig. 3B). Interestingly, overexpression of Bid(D59A) also potently induced cell death in the hippocampal neuron cultures, reaching a level of $73.5 \pm 3.1 \%$ after $24 \mathrm{~h}(\mathrm{p}>0.1$, no significant difference compared to FL-Bid induced cultures).

\section{Discussion}

Ischemic and hypoxic injuries to the nervous system have been shown to involve the release of cell death-inducing cytokines and the activation of death receptors [19]. It is likely that these events involve the caspase-8-mediated cleavage of the BH3-only protein Bid. In support of this hypothesis, Bid-deficient animals exhibited reduced neuronal injury after cerebral ischaemia [19]. Our data provide evidence that Bid may be involved in an additional, intrinsic cell death pathway triggered by the overactivation of glutamate receptors. This pathway did not require the generation of the caspase-8-generated cleavage product tBid. Instead, we observed an efficient translocation of FL-Bid to mitochondria during excitotoxic neuron death. This translocation was associated with the mitochondrial release of pro-apoptotic factors, a process that commits cells to both caspase-dependent and caspase-independent cell death $[33,34]$. Although our data does not rule out the possibility that other $\mathrm{BH} 3$ only proteins are involved in excitotoxic apoptosis, it demonstrates that FL-Bid is sufficient to induce an apoptotic cell death in cultured rat hippocampal neurons.

There is growing evidence that the caspase cascade may not be potently activated during excitotoxic neuron death, despite the release of cyt-C from mitochondria [6$10,27,28]$. We and others have previously demonstrated that calpains activated during excitotoxicity degrade and inactivate essential components of the caspase activating pathway including APAF-1, procaspase-9, -8, and -3 $[8,35,36]$. There is also evidence that levels of Apaf- 1 decrease during neuronal maturation, inhibiting apoptosome formation after mitochondrial outer membrane permeabilization (MOMP) [37]. In the absence of caspase activation MOMP may activate alternative cell death pathways that include ATP depletion and increased ROS production subsequent to cyt- $\mathrm{C}$ release, as well as the release of AIF [7,9,38-40].

In contrast to death receptor-induced apoptosis we could not detect significant amounts of cleaved Bid accumulating in the cultured rat hippocampal neurons in response to NMDA. However, we cannot exclude the possibility that Bid may be cleaved during the later stages of apoptosis, downstream of MOMP or an intracellular ion homeostasis breakdown [28,41,42]. These cells will subsequently undergo plasma membrane leakage, a proc- 
A

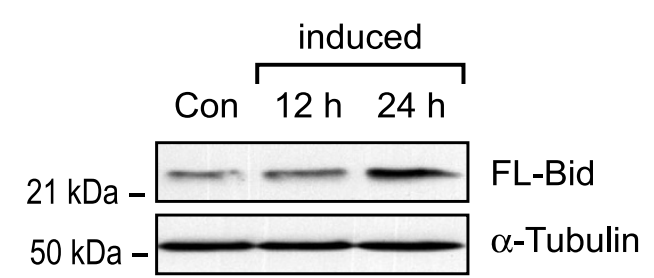

B

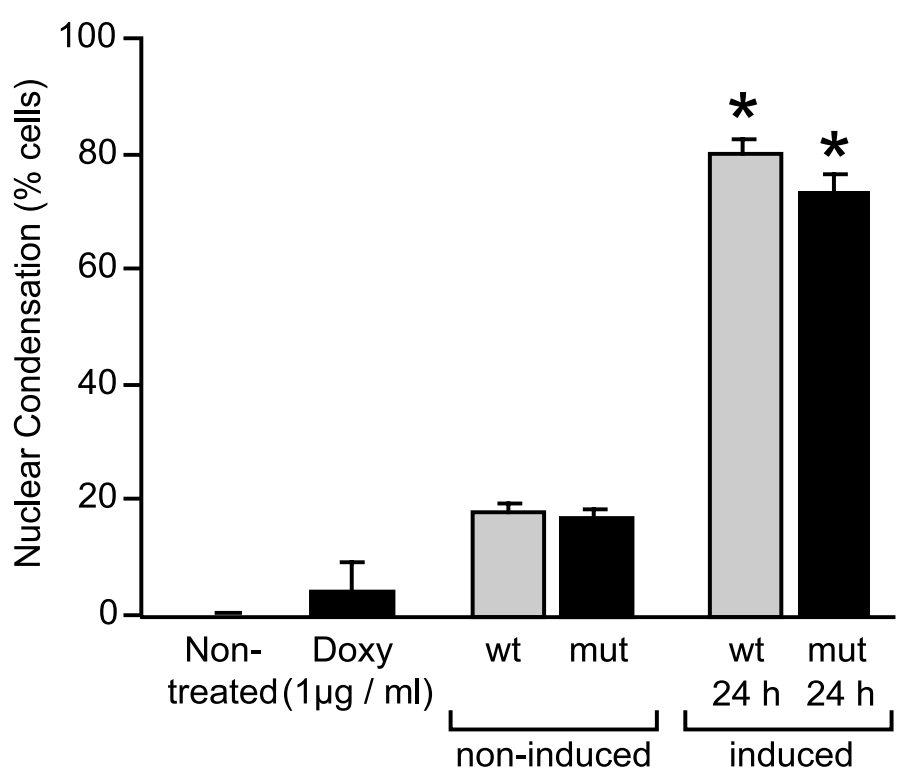

C

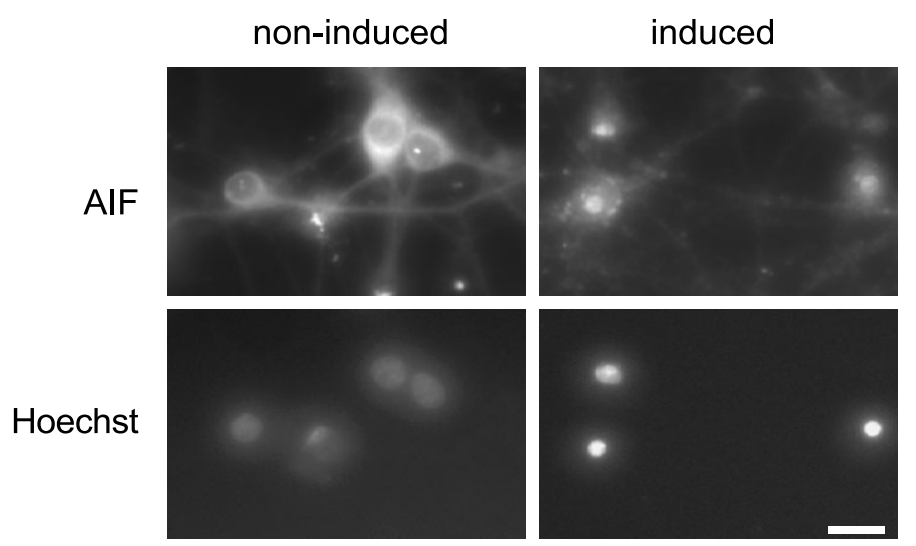

Figure 3

FL-Bid or a Bid mutant that can not be cleaved by caspase-8 potently induces cell death in cultured rat hippocampal neurons. (A)Western blot analysis of Bid overexpression in cultured rat hippocampal neurons. Cells were co-infected with the wild-type (wt) FL-Bid adenovirus and the rtTA containing virus. Expression of Bid was induced by I $\mu \mathrm{g} / \mathrm{ml}$ doxycycline treatment for 12 or $24 \mathrm{~h}$. Control cells were infected but not induced. (B)Quantification of cells showing nuclear condensation in response to an overexpression of wt FL-Bid or the Bid(D59A) mutant (mt). Cells were co-infected with the wt or mt FL-Bid adenovirus and the rtTA containing virus. After $48 \mathrm{~h}$, expression of Bid was induced by the addition of I $\mu \mathrm{M}$ doxycycline for 12 or $24 \mathrm{~h}$. Cells exhibiting nuclear condensation or nuclear fragmentation were counted in $4-5$ randomly chosen subfields after staining with the chromatin-specific dye Hoechst 33528. Data are means \pm SEM from $n=3$ experiments. (C)AIF immunofluorescence analysis in non-induced and induced hippocampal neurons. Cells were co-infected with the wt FL-Bid adenovirus and the rtTA containing virus and induced for $12 \mathrm{~h}$. Note the mitochondrial AIF immunofluorescence in non-induced cells sparing the nuclear region, and AIF translocation to the nucleus in the induced neuron cultures. Bar $=10 \mu \mathrm{m}$. 
ess that may limit the ability to detect Bid cleavage during the late stages of apoptosis. A previous report has demonstrated that translocation of FL-Bid to mitochondria may also occur in response to an activation of death receptors when caspase- 8 activation is blocked by the addition of a caspase- 8 inhibitor [43]. In Bid- and caspase-8-deficient mouse embryonic fibroblasts, FL-Bid or the non-cleavable mutant FL-Bid(D59A) are also sufficient to activate apoptosis [32]. In line with this finding we found no significant difference in the ability of FL-Bid and Bid(D59A) to induce cell death in cultured rat hippocampal neurons.

How may NMDA receptor overactivation stimulate FL-Bid translocation? Previous studies have demonstrated that excitotoxic neuron death is associated with a selective inhibition of phosphatidylcholine synthesis [44]. It has also been shown that physiological concentrations of phosphatidic acid and phosphatidylgycerol are able to induce an accumulation of FL-Bid in mitochondria [45]. FL-Bid has been shown to be sufficient to induce the oligomerization of $\mathrm{Bax} / \mathrm{Bak}$, resulting in its integration into the outer mitochondrial membrane triggering cyt- $\mathrm{C}$ release [24]. Finally, recombinant FL-Bid displayed lipid transfer activity under the same conditions and at the same nanomolar concentrations that lead to mitochondrial translocation and Cyt-C release [45]. Changes in the intracellular phospholipid environment during excitotoxic cell death signals may hence induce the translocation of FL-Bid to mitochondria and may initiate the release of pro-apoptotic factors from mitochondria.

\section{Conclusion}

Bid is highly expressed in the nervous system during embryonic and postnatal development. Interestingly and in contrast to most $\mathrm{BH} 3$ only proteins, Bid expression remains high in the adult nervous system [29]. The ability of both tBid and FL-Bid to translocate to mitochondria and to induce cell death suggest that this BH3-only protein is a central mediator of pathophysiological neuron death.

\section{Methods \\ Materials}

N-Methyl-D-aspartate (NMDA), recombinant tumor necrosis factor- $\alpha$ (TNF- $\alpha$ ), glycin and cycloheximide (CHX) came from Sigma (Poole, Dorset, U.K.). Tetrodotoxin was purchased from Biotrend (Cologne, Germany), CA-074 methyl ester (CA-074-ME) from Calbiochem (Bad Soden, Germany), and staurosporine (STS) from Alexis (Grünberg, Germany).

\section{Cell Culture}

Cultured hippocampal neurons were prepared from neonatal (P1) Fischer 344 rats (Luetjens et al., 2000). Dissociated hippocampal neurons were plated at a density of $2 \times$
$10^{5}$ cells $/ \mathrm{cm}^{2}$ into poly-L-lysine-coated 6- or 24-well plates or glass chamber slides (Nunc). Cells were maintained in MEM medium supplemented with 10\% NU-serum, 2\% B27 supplement ( $50 \times$ concentrate), $2 \mathrm{mM}$ L-glutamine, 20 $\mathrm{mM}$ D-glucose, $26.2 \mathrm{mM}$ sodium bicarbonate, $100 \mathrm{U} / \mathrm{ml}$ penicillin and $100 \mu \mathrm{g} / \mathrm{ml}$ streptomycin (Life Technologies, Karlsruhe, Germany). Experiments were performed on 14 - 16 day-old cultures. Animal care followed official governmental guide lines. HeLa D98 cells were cultured in RPMI 1640 medium (Life Technologies, Germany) supplemented with $10 \%$ fetal calf serum (PAA, Cölbe, Germany).

\section{Excitotoxic neuronal injury}

Cultures were exposed for $5 \mathrm{~min}$ to $\mathrm{Mg}^{2+}$-free Hepes-buffered saline (HBS) supplemented with $300 \mu \mathrm{M}$ NMDA, 0.5 $\mu \mathrm{M}$ tetrodotoxin and $1 \mu \mathrm{M}$ glycine $[7,8]$. Control cultures were exposed to $\mathrm{Mg}^{2+}$-free HBS devoid of NMDA (sham exposure). Cell death was determined after $24 \mathrm{~h}$ by trypan-blue uptake [7]. Experiments were performed on 14 or 15 day-old cultures.

Generation of adenoviral vectors expressing FL-Bid or FLBid(D59A) in an inducible system and infection protocol Tetracycline (tet)-on inducible adenovirus vectors expressing wild-type FL-Bid or the D59A mutant of FL-Bid that can not be cleaved by caspase- 8 were generated as described previously [32]. Hippocampal neurons were infected at a MOI (multiplicity of infection) of 50 with both the FL-Bid or Bid(D59A) containing viruses and the reverse tet transactivator rtTA containing virus. One $\mu \mathrm{g} / \mathrm{ml}$ doxycycline (Sigma) was added to the medium $24 \mathrm{~h}$ post infection to activate gene expression from the tet-inducible promoter [32].

\section{Immunofluorescence microscopy}

Hippocampal neurons were washed, fixed with formaldehyde, and permeabilized with Tween-20 (0.3\%). The following primary antibodies were used: mouse monoclonal anti-cyt-C (6H2.B4, San Diego, CA; $10 \mu \mathrm{g} / \mathrm{ml})$, rabbit polyclonal anti-Bid raised against amino acids $1-58$ of mouse Bid (AR-53; 1:1,000), and rabbit polyclonal antiApoptosis-Inducing-Factor (AIF) (1:500; [46]). Nuclei were counterstained with Hoechst33258. Primary antibodies were detected and fluorescent images acquired as described previously [7].

\section{Digitonization, SDS-PAGE, and Western blotting}

The release of cyt-C from mitochondria was analyzed by selective permeabilization of the plasma membrane [47]. Briefly, cells were permeabilized with $100 \mu \mathrm{g} / \mathrm{ml}$ digitonin at $4^{\circ} \mathrm{C}$ for $10 \mathrm{~min}$. The supernatant representing the cytosol and the mitochondria-containing pellet fraction were separated by centrifugation and denatured. SDSPAGE and Western blot analysis was performed as 
described previously [8]. Cyt-C was detected with a monoclonal Cyt-C antibody (7H8.2C12; Pharmingen), Bid with the rabbit polyclonal antibody diluted 1:2,000, VDAC (Porin) and HSP-90 with mouse monoclonal antiPorin (31HL, Calbiochem) and anti-HSP90 $\alpha / \beta$ (Santa Cruz, Heidelberg, Germany) antibodies, respectively, at a dilution of 1:5,000. $\alpha$-spectrin and its calpain-generated cleavage products were detected with a mouse monoclonal antibody (1622; Chemicon) diluted 1:5,000, and $\alpha$-tubulin with a mouse monoclonal antibody (DM-1A; Sigma) diluted 1:1,000.

\section{Statistics}

Data are given as means \pm S.E.M. For statistical comparison, one-way analysis of variance followed by Tukey's test were employed. P values smaller than 0.05 were considered to be statistically significant.

\section{Authors' contributions}

HGK carried out the molecular analyses, participated in the sequence alignment and drafted the manuscript.

MR carried out the immunoassays.

DG participated in the sequence alignment.

SK participated in the design of the study and performed the statistical analysis.

MW carried out immunofluorescence, participated in its design and coordination and helped to draft the manuscript.

JHMP conceived of the study, and participated in its design and coordination and helped to draft the manuscript.

All authors have read and approved the final manuscript

\section{Additional material}

\section{Additional File 1}

Long exposures for Figure 1A, B and 1C. The abundance of the FL-Bid in relation to the cleaved-Bid fragments is depicted on one blot. In contrast to STS and TNF- $\alpha$ treated HeLa cells no such band is visible after treatment of the hippocampal neurons with NMDA.

Click here for file

[http://www.biomedcentral.com/content/supplementary/14712121-8-7-S1.pdf]

\section{Acknowledgements}

The authors thank Hanni Bähler, Helena Bonner and Christiane Schettler for technical assistance, Dr. Richard C. Marcellus for his help preparing the adenoviral vectors, Dr. Marcel Leist for the AIF antibody. This work was supported by grants from the European Union (MTKD-CT-2004-014499), NIH Grant (NS3682I) to S.K. and Science Foundation Ireland (03/RP/B344) to J.H.M.P.

\section{References}

I. Choi DW: Glutamate receptors and the induction of excitotoxic neuronal death. Prog Brain Res 1994, 100:47-5I.

2. Choi DW: Ionic dependence of glutamate neurotoxicity. J Neurosci 1987, 7(2):369-379.

3. Ankarcrona M, Dypbukt JM, Bonfoco E, Zhivotovsky B, Orrenius $S$, Lipton SA, Nicotera P: Glutamate-induced neuronal death: a succession of necrosis or apoptosis depending on mitochondrial function. Neuron 1995, I 5(4):961-973.

4. Budd SL, Nicholls DG: Mitochondria, calcium regulation, and acute glutamate excitotoxicity in cultured cerebellar granule cells. J Neurochem 1996, 67(6):2282-229I.

5. White RJ, Reynolds IJ: Mitochondrial depolarization in glutamate-stimulated neurons: an early signal specific to excitotoxin exposure. J Neurosci 1996, I6( I 8):5688-5697.

6. Budd SL, Tenneti L, Lishnak T, Lipton SA: Mitochondrial and extramitochondrial apoptotic signaling pathways in cerebrocortical neurons. Proc Natl Acad Sci USA 2000, 97(I I):6I6I-6I66.

7. Luetjens CM, Bui NT, Sengpiel B, Munstermann G, Poppe M, Krohn A), Bauerbach E, Krieglstein J, Prehn JH: Delayed mitochondrial dysfunction in excitotoxic neuron death: cytochrome c release and a secondary increase in superoxide production. J Neurosci 2000, 20(I5):57| 5-5723.

8. Lankiewicz S, Marc Luetjens C, Truc Bui N, Krohn AJ, Poppe M, Cole GM, Saido TC, Prehn JH: Activation of calpain I converts excitotoxic neuron death into a caspase-independent cell death. J Biol Chem 2000, 275(22): I7064-I707I.

9. Yu SW, Wang H, Poitras MF, Coombs C, Bowers WJ, Federoff H], Poirier GG, Dawson TM, Dawson VL: Mediation of poly(ADP. ribose) polymerase-I-dependent cell death by apoptosisinducing factor. Science 2002, 297(5579):259-263.

10. Wang H, Yu SW, Koh DW, Lew J, Coombs C, Bowers W, Federoff HJ, Poirier GG, Dawson TM, Dawson VL: Apoptosis-inducing factor substitutes for caspase executioners in NMDA-triggered excitotoxic neuronal death. I Neurosci 2004, 24(48): $10963-10973$.

II. Wei MC, Zong WX, Cheng EH, Lindsten T, Panoutsakopoulou V, Ross AJ, Roth KA, MacGregor GR, Thompson CB, Korsmeyer SJ: Proapoptotic BAX and BAK: a requisite gateway to mitochondrial dysfunction and death. Science 200I, 292(55 I 7): $727-730$.

12. Kuwana T, Mackey MR, Perkins G, Ellisman MH, Latterich M, Schneiter R, Green DR, Newmeyer DD: Bid, Bax, and lipids cooperate to form supramolecular openings in the outer mitochondrial membrane. Cell 2002, I I I(3):33I-342.

13. Goping IS, Gross A, Lavoie JN, Nguyen M, Jemmerson R, Roth K, Korsmeyer SJ, Shore GC: Regulated targeting of BAX to mitochondria. J Cell Biol 1998, I 43(I):207-2I5.

14. Eskes R, Antonsson B, Osen-Sand A, Montessuit S, Richter C, Sadoul R, Mazzei G, Nichols A, Martinou JC: Bax-induced cytochrome C release from mitochondria is independent of the permeability transition pore but highly dependent on $\mathrm{Mg2+}$ ions. J Cell Biol 1998, I43(I):217-224.

15. Huang DC, Strasser A: BH3-Only proteins-essential initiators of apoptotic cell death. Cell 2000, 103(6):839-842.

16. Green DR: At the gates of death. Cancer Cell 2006, 9(5):328-330.

17. Susin SA, Zamzami N, Castedo M, Hirsch T, Marchetti P, Macho A, Daugas E, Geuskens M, Kroemer G: Bcl-2 inhibits the mitochondrial release of an apoptogenic protease. J Exp Med 1996, 184(4): |33|-|34|.

18. Wang HG, Pathan N, Ethell IM, Krajewski S, Yamaguchi Y, Shibasaki F, McKeon F, Bobo T, Franke TF, Reed JC: Ca2+-induced apoptosis through calcineurin dephosphorylation of BAD. Science 1999, 284(54 | 2):339-343.

19. Plesnila N, Zinkel S, Le DA, Amin-Hanjani S, Wu Y, Qiu J, Chiarugi A, Thomas SS, Kohane DS, Korsmeyer SJ, et al.: BID mediates neuronal cell death after oxygen/glucose deprivation and focal cerebral ischemia. Proc Natl Acad Sci USA 200I, 98(26): I53।8-I 5323.

20. $\mathrm{Li} \mathrm{H}, \mathrm{Zhu} \mathrm{H}, \mathrm{Xu} \mathrm{CJ}$, Yuan J: Cleavage of BID by caspase 8 mediates the mitochondrial damage in the Fas pathway of apoptosis. Cell I998, 94(4):49|-50I. 
21. Luo X, Budihardjo I, Zou H, Slaughter C, Wang X: Bid, a Bcl2 interacting protein, mediates cytochrome c release from mitochondria in response to activation of cell surface death receptors. Cell 1998, 94(4):48I-490.

22. Zha J, Weiler S, Oh KJ, Wei MC, Korsmeyer SJ: Posttranslational $\mathbf{N}$-myristoylation of BID as a molecular switch for targeting mitochondria and apoptosis. Science 2000 290(5497): $1761-1765$.

23. Wei MC, Lindsten T, Mootha VK, Weiler S, Gross A, Ashiya M, Thompson CB, Korsmeyer SJ: tBID, a membrane-targeted death ligand, oligomerizes BAK to release cytochrome c. Genes Dev 2000, 14(16):2060-2071.

24. Eskes R, Desagher S, Antonsson B, Martinou JC: Bid induces the oligomerization and insertion of Bax into the outer mitochondrial membrane. Mol Cell Biol 2000, 20(3):929-935.

25. Armstrong RC, Aja TJ, Hoang KD, Gaur S, Bai X, Alnemri ES, Litwack G, Karanewsky DS, Fritz LC, Tomaselli KJ: Activation of the CED3/ICE-related protease CPP32 in cerebellar granule neurons undergoing apoptosis but not necrosis. J Neurosci 1997, I7(2):553-562.

26. Johnson MD, Kinoshita Y, Xiang H, Ghatan S, Morrison RS: Contribution of p53-dependent caspase activation to neuronal cell death declines with neuronal maturation. J Neurosci 1999 19(8):2996-3006.

27. Cao J, Semenova MM, Solovyan VT, Han J, Coffey ET, Courtney MJ: Distinct requirements for $\mathrm{p} 38$ alpha and c-Jun $\mathrm{N}$-terminal kinase stress-activated protein kinases in different forms of apoptotic neuronal death. J Biol Chem 2004, 279(34):35903-359/3.

28. Ward MW, Rehm M, Duessmann H, Kacmar S, Concannon CG, Prehn JH: Real Time Single Cell Analysis of Bid Cleavage and Bid Translocation during Caspase-dependent and Neuronal Caspase-independent Apoptosis. J Biol Chem 2006, 28 I(9):5837-5844.

29. Krajewska M, Mai JK, Zapata JM, Ashwell KW, Schendel SL, Reed JC, Krajewski S: Dynamics of expression of apoptosis-regulatory proteins Bid, Bcl-2, Bcl-X, Bax and Bak during development of murine nervous system. Cell Death Differ 2002, 9(2): I 45-I57.

30. Franz G, Beer R, Intemann D, Krajewski S, Reed JC, Engelhardt K, Pike BR, Hayes RL, Wang KK, Schmutzhard E, et al.: Temporal and spatial profile of Bid cleavage after experimental traumatic brain injury. J Cereb Blood Flow Metab 2002, 22(8):95I-958.

31. Neame SJ, Rubin LL, Philpott KL: Blocking cytochrome c activity within intact neurons inhibits apoptosis. J Cell Biol 1998, | 42(6): I 583-| 593 .

32. Sarig R, Zaltsman Y, Marcellus RC, Flavell R, Mak TW, Gross A: BIDD59A is a potent inducer of apoptosis in primary embryonic fibroblasts. I Biol Chem 2003, 278(I 2): I0707-107/5.

33. Kogel D, Prehn JHM: Caspase-independent cell death pathways. In Caspases - their role in cell death and cell survival Edited by: Los M, Walczak H. Kluwer Academic Press; 2002:237-248. (Caspases-their role in cell death and cell survival)

34. Kroemer G, Martin S): Caspase-independent cell death. Nat Med 2005, II (7):725-730.

35. Chua BT, Guo K, Li P: Direct cleavage by the calcium-activated protease calpain can lead to inactivation of caspases. J Bio Chem 2000, 275(7):5|3|-5|35.

36. Reimertz C, Kogel D, Lankiewicz S, Poppe M, Prehn JH: Ca(2+)induced inhibition of apoptosis in human SH-SY5Y neuroblastoma cells: degradation of apoptotic protease activating factor-I (APAF-I). J Neurochem 200I, 78(6): I256-I 266.

37. Wright KM, Linhoff MW, Potts PR, Deshmukh M: Decreased apoptosome activity with neuronal differentiation sets the threshold for strict IAP regulation of apoptosis. J Cell Biol 2004, 167(2):303-3I3.

38. Krippner A, Matsuno-Yagi A, Gottlieb RA, Babior BM: Loss of function of cytochrome $\mathrm{c}$ in Jurkat cells undergoing fas-mediated apoptosis. J Biol Chem 1996, 27 I(35):21629-21636.

39. Cai J, Jones DP: Superoxide in apoptosis. Mitochondrial generation triggered by cytochrome c loss. I Biol Chem 1998 273(19): I|40I-II404.

40. Cregan SP, Fortin A, MacLaurin JG, Callaghan SM, Cecconi F, Yu SW, Dawson TM, Dawson VL, Park DS, Kroemer G, et al.: Apoptosisinducing factor is involved in the regulation of caspase-independent neuronal cell death. J Cell Biol 2002, I 58(3):507-5I7.
4I. Ward MW, Rego AC, Frenguelli BG, Nicholls DG: Mitochondrial membrane potential and glutamate excitotoxicity in cultured cerebellar granule cells. I Neurosci 2000, 20(19):7208-7219.

42. Bano D, Young KW, Guerin CJ, Lefeuvre R, Rothwell NJ, Naldini L, Rizzuto R, Carafoli E, Nicotera P: Cleavage of the plasma membrane $\mathrm{Na}+/ \mathrm{Ca} 2+$ exchanger in excitotoxicity. Cell 2005, I 20(2):275-285.

43. Tafani M, Karpinich NO, Hurster KA, Pastorino JG, Schneider T, Russo MA, Farber JL: Cytochrome c release upon Fas receptor activation depends on translocation of full-length bid and the induction of the mitochondrial permeability transition. J Biol Chem 2002, 277(1 2): 10073-10082.

44. Gasull T, DeGregorio-Rocasolano N, Zapata A, Trullas R: Choline release and inhibition of phosphatidylcholine synthesis precede excitotoxic neuronal death but not neurotoxicity induced by serum deprivation. I Biol Chem 2000, 275(24): | 8350- 18357.

45. Esposti MD, Erler JT, Hickman JA, Dive C: Bid, a widely expressed proapoptotic protein of the $\mathrm{Bcl}-2$ family, displays lipid transfer activity. Mol Cell Biol 200I, 2I(2I):7268-7276.

46. Suter M, Reme C, Grimm C, Wenzel A, Jaattela M, Esser P, Kociok N, Leist M, Richter C: Age-related macular degeneration. The lipofusion component $\mathbf{N}$-retinyl- $\mathbf{N}$-retinylidene ethanolamine detaches proapoptotic proteins from mitochondria and induces apoptosis in mammalian retinal pigment epithelial cells. J Biol Chem 2000, 275(50):39625-39630.

47. Luetjens CM, Kogel D, Reimertz C, Dussmann H, Renz A, SchulzeOsthoff K, Nieminen AL, Poppe M, Prehn JH: Multiple kinetics of mitochondrial cytochrome $c$ release in drug-induced apoptosis. Mol Pharmacol 200I, 60(5): 1008-1019.
Publish with Bio Med Central and every scientist can read your work free of charge

"BioMed Central will be the most significant development for disseminating the results of biomedical research in our lifetime. "

Sir Paul Nurse, Cancer Research UK

Your research papers will be:

- available free of charge to the entire biomedical community

- peer reviewed and published immediately upon acceptance

- cited in PubMed and archived on PubMed Central

- yours - you keep the copyright
BiolMedcentral 